\title{
Carbon Partitioning in Potted Post-Véraison Vitis vinifera L. cv. Riesling Vines: Effect of Dormant Cane Length
}

\author{
W.P. Stewart ${ }^{1}$, B.M. Freeman ${ }^{2}$ and J.K. Dick ${ }^{2}$ \\ 1) Department of Employment, Training and Further Education, P.O. Box 208, Nuriootpa, South Australia 5355, Australia \\ 2) Charles Sturt University - Riverina, P.O. Box 588, Wagga Wagga, N.S.W., 2678, Australia
}

Submitted for publication: June 1996

Accepted for publication: October 1996

Key words: Vitis vinifera, Riesling, carbon partitioning, ${ }^{14} \mathrm{C}$, dormant cane length

\begin{abstract}
To investigate the movement of photoassimilates within a wine canopy, potted Vitis vinifera L. cv. Riesling grapevines were pruned to two different dormant cane lengths of $100 \mathrm{~mm}$ and $900 \mathrm{~mm}$. Shoots on these canes were vertically trained with one non-fruitbearing shoot growing from the apical node and one fruit-bearing shoot growing from the basal node for each treatment.. Known quantities of ${ }^{14} \mathrm{CO}$, were loaded into the source leaf located at leaf node position 10 on the apical shoot. Bi-directional translocation of ${ }^{14} \mathrm{C}$ photoassimilates was demonstrated. Minimal translocation of ${ }^{14} \mathrm{C}$ photoassimilates from source leaves on non-fruit-bearing shoots was directed towards the clusters located on the lower shoot. The non-fruit-bearing shoots are, however, contributing to the carbohydrate reserves in the roots, where an allocation of over $50 \%$ of the exported ${ }^{14} \mathrm{C}$ photoassimilates to the roots was demonstrated in both treatments.
\end{abstract}

${ }^{14}$ Carbon $\left({ }^{14} \mathrm{C}\right)$ photoassimilates distribution patterns from source leaves of grapevines have previously been investigated and reported. Quinlan \& Weaver (1970) demonstrated that the direction of ${ }^{14} \mathrm{C}$ labelled photosynthate translocation changed from acropetal to basipetal for the same leaf during the growing season and that prior to the flowering stage there was no translocation of ${ }^{14} \mathrm{C}$ photosynthate between adjacent shoots on the same spur. Translocation from one shoot to the next was only induced following the application of gibberellic acid, shading or defoliation of the unlabelled shoot.

Extensive ${ }^{14} \mathrm{C}$ translocation studies have been completed by Hunter \& Visser (1988a, 1988b). Their studies have focused on percentage defoliation regimes, leaf position and developmental stages of vine growth in relation to carbon partitioning. There was no change recorded in the distribution or direction of photoassimilates between the defoliation treatments. By increasing the number of clusters on the shoot Motomura (1990) showed that the percentage of ${ }^{14} \mathrm{C}$ translocated into the clusters increased as did the percentage export from the source leaves. In investigating the effects of shoot tip removal, shoot girdling and leaf halving in grapevines, Motomura (1993) confirmed the influence of phyllotaxis on assimilate partitioning. Partitioning of ${ }^{14} \mathrm{C}$ to the roots was not examined in any of the above investigations.

A series of pot experiments was designed to compare the extent and direction of the transfer of ${ }^{14} \mathrm{C}$ photoassimilates in grapevines with varying source to sink pathways. Stewart et al. (1996) reported on carbon partitioning in single shoots of Riesling grapevines. This paper reports on the results of ${ }^{14} \mathrm{C}$ photoassimilate translocation from source leaves on non-fruit-bearing shoots to fruit-bearing shoots in post-véraison Riesling grapevines.

\section{MATERIALS AND METHODS}

Grapevine growing conditions: One-year-old cv. Riesling rootlings were planted in 1991 in 10 litre plastic growbags containing a mixture of coarse washed river sand, composted horticultural grade hardwood barkchips and composted hardwood sawdust mixed in equal proportions. All pots were placed in a $0,5 \mathrm{~m}$ by $0,5 \mathrm{~m}$ grid pattern exposed to full sunlight. During the experiments the grapevines were fertilised weekly with a 0,5 litre solution of 0,5 gram per litre Aquasol (a soluble fertiliser, NPK 23:4:12, manufactured by Hortico (Australia) Pty., Ltd.) per grapevine.

From August to 28 October 1992 the grapevines were watered by an automatic overhead irrigation system which gave each grapevine $20 \mathrm{~mm}$ of water per day. This was increased to $30 \mathrm{~mm}$ per day from early November. No water stress symptoms were observed during the experiments. Shoots were trained vertically on strings attached to the roof of the shadehouse and all lateral growth was removed weekly by hand. On 1 December 1992 cluster number per grapevine was reduced to one and all leaves below the cluster were removed and clusters were adjusted to 50 berries per cluster per grapevine 16 days later.

The selected grapevine population was divided into two treatments of twelve potted grapevines. On 20 August 1992 all potted grapevines within the experiment were pruned to two dormant cane lengths. The first treatment (T1) had a dormant cane length of $100 \mathrm{~mm}$ while the second treatment (T2) had a dormant cane length of $900 \mathrm{~mm}$. One shoot was allowed to grow from the basal node and one shoot from the apical node of canes in both treatments. All shoot growth from the remaining buds was removed at budburst. Both treatments then consisted of twelve potted grapevines 
with two vertically trained shoots with only the lower shoot bearing a single cluster.

${ }^{14}$ Carbon dioxide loading technique: The leaf at the tenth node position on the non-fruit-bearing apical shoot was loaded with ${ }^{14}$ carbon dioxide $\left({ }^{14} \mathrm{CO}_{2}\right)$ for both treatments. The grapevines used in this experiment were loaded with ${ }^{14} \mathrm{CO}_{2} 172$ days after pruning. At this stage the shoot apices had ceased growing as indicated by the tip of the youngest leaf not extending beyond the shoot apex and berry deformability had markedly increased. The ${ }^{14} \mathrm{CO}_{2}$ generating method used was an adaptation from Hunter \& Visser (1988a) whereby a 2,0 cubic centimetres $\left(\mathrm{cm}^{3}\right)$ polyethylene vial containing a $0,5 \mathrm{~cm}^{3}$ solution of $20 \%(\mathrm{w} / \mathrm{v})$ lactic acid was attached to the petiole of the leaf, which was enclosed in a clear polyethylene bag. The loading period was initiated by the injection of $0,05 \mathrm{~cm}^{3}$ of sodium hydrogen carbonate $\left(\mathrm{NaH}^{14} \mathrm{Co}_{3}\right)$ with a total radioactivity of 185 kiloBequerels $(\mathrm{kBq})$ into the polyethylene vial. The polyethylene bag was tightly sealed and assimilation of ${ }^{14} \mathrm{CO}_{2}$ was allowed for 1 hour.

Harvesting procedure: Twenty-four hours after the ${ }^{14} \mathrm{CO}_{2}$ loading period all grapevines for each treatment were harvested into leaves, shoots, clusters, rachis, roots, shoot and cane sections. Leaf areas were measured using a Delta $\mathrm{T}$ leaf area meter (Delta $\mathrm{T}$ Devices, Cambridge, United Kingdom). The roots were washed to remove any adhering potting mix prior to drying. The leaves, rachis, roots and cane/shoot sections were dried at $60^{\circ} \mathrm{C}$ for three days in a fan-forced dehydrator and dry mass were recorded. The dried source leaf material was finely ground in a mortar and pestle while the remaining plant material was finely ground in a plant grinding mill. The grape berries were separated from the rachis, stored frozen, then freeze dried for seven days, weighed and ground in a mortar and pestle.

Sample oxidation/Scintillation counting: Duplicate 0,2 gram subsamples for all dried plant parts were combusted in a Packard Tri-Carb 307 Sample Oxidiser using Carbo Sorb E as the absorbent (Canberra Packard (Australia) Pty., Ltd.) and Permafluor V as the scintillation cocktail (Canberra Packard (Australia) Pty., Ltd). The radioactivity of the oxidised samples was then measured using a Beckman Scintillation Counter.

Statistical analysis: All data were analysed using the standard analyses of variance methods of Snedecor and Cochrane (1969). The Student's least significant difference at the $0,1 \%, 1 \%$ and $5 \%$ level was used to compare treatment means.

\section{RESULTS AND DISCUSSION}

The Riesling grapevines used in this experiment showed a significant difference between treatment means for both total leaf area and total leaf dry mass (Table 1). The leaf area for the non-fruiting apical shoot in T1 was $0.2432 \mathrm{~m}^{2}$, which is nearly identical to the $0.2452 \mathrm{~m}^{2}$ of leaf area for the same shoot in T2. There was a large difference in leaf area between the basal fruit-bearing shoots of the two treatments, where $\mathrm{T} 1 \mathrm{had}$ an area of $0.2566 \mathrm{~m}^{2}$ as compared to $\mathrm{T} 2$ with an area of $0.1010 \mathrm{~m}^{2}$. This phenomenon is generally observed in field situations. However, mean cluster dry mass between treatments were not significantly different. Mean cluster fresh mass values were $28,82 \mathrm{~g}$ for $\mathrm{T} 1$ and 26,75 $\mathrm{g}$ for T2. Total plant dry mass was not significantly different between treatments. Root to shoot (total vegetative) dry mass ratios for each treatment were similar with values of 1,18 for T1 and 1,30 for T2.

When the leaf area per gram of fresh fruit value (LA/F) is calculated, T1 has an LA/F value of $173,4 \mathrm{~cm}^{2} / \mathrm{g}$ while $\mathrm{T} 2$ has an $\mathrm{LA} / \mathrm{F}$ value of $129,4 \mathrm{~cm}^{2} / \mathrm{g}$. These values are higher than the LA/F values obtained by Stewart et al. (1996) and well above the optimum range $(6,0$ to 15,0 $\mathrm{cm}^{2} / \mathrm{g}$ ) for ripening field-grown grapevines (Smart et al., 1990). A reduction in berry number to 50 berries per cluster resulted in the high LA/F values for this experiment.

Leaf 10 in $\mathrm{T} 1$ exported $47,7 \%$ of the assimilated ${ }^{14} \mathrm{C}$, while leaf 10 in $\mathrm{T} 2$ exported $42,4 \%$. There was no translocation of ${ }^{14} \mathrm{C}$ photoassimilates to leaves below the source leaf in both treatments, which agrees with the results of Stewart et al. (1996). Leaf 10 in T1 translocated 2,42\% of the ${ }^{14} \mathrm{C}$ photoassimilates towards the apex $(0,21 \%$ to the leaves and $2,21 \%$ to the shoot) while leaf 10 in T2 exported $1,48 \%$ of the ${ }^{14} \mathrm{C}$ photoassimilates towards the apex $(1,09 \%$ to the leaves and $0,39 \%$ to the shoot) (Table 2). This result concurs with the results of Stewart et al. (1996), where a small percentage of ${ }^{14} \mathrm{C}$ photoassimilates was directed towards the apex.

The percentage of exported ${ }^{14} \mathrm{C}$ photoassimilates that accumulated in the roots of $\mathrm{T} 1$ was $57,8 \%$ and $51,9 \%$ for $\mathrm{T} 2$. These results are much higher than the results obtained for ${ }^{14} \mathrm{C}$ photoassimilate accumulation in the roots in both treatments obtained by Stewart et al. (1996). The non-fruitbearing shoot is therefore contributing to root carbohydrate reserves at this stage of the growth season or alternatively it may be supporting the normal maintenance requirements of the root system. Dormant cane length had no effect on the percentage of ${ }^{14} \mathrm{C}$ photoassimilates that were translocated to the roots for each treatment. The percentage of exported ${ }^{14} \mathrm{C}$ photoassimilates that accumulated in the cane and shoot below the loaded leaf to the basal shoot node for each treatment was $20,96 \%$ for T1 $(18,92 \%$ in the shoot below and 2,04\% in the cane) and $29,73 \%$ for T2 $(16,54 \%$ in the shoot and $13,19 \%$ in the cane). The higher accumulation found in the canes of the latter is a function of their total length and mass. When the specific radioactivity of these shoot sections is expressed as $\mathrm{kBq}$ per gram dry mass, the respective values are $0,38 \mathrm{kBq} / \mathrm{g}$ for $\mathrm{T} 1$ and 0,46 $\mathrm{kBq} / \mathrm{g}$ for $\mathrm{T} 2$. The percentage of exported ${ }^{14} \mathrm{C}$ photoassimilates that accumulated in the cluster and rachis of each treatment was significantly different $(\mathrm{p}<0.5)$ with T1 accumulating $14,3 \%$ and $\mathrm{T} 210,8 \%$. 
TABLE 1

Leaf area $\left(\mathrm{m}^{2}\right)$, dry mass $(\mathrm{g})$ and total specific radioactivity $(\mathrm{kBq})$ of Vitis vinifera $\mathrm{L}$. cv. Riesling grapevines treated with ${ }^{14} \mathrm{CO}_{2}$ at leaf 10 on the non-fruit-bearing apical shoots carried on $100 \mathrm{~mm}$ (T1) and $900 \mathrm{~mm}$ (T2) canes. Each data point is the mean value of 12 plants.

\begin{tabular}{|c|c|c|c|c|c|c|}
\hline \multirow[b]{2}{*}{ Plant organ } & \multicolumn{3}{|c|}{ T1 (100 mm dormant cane) } & \multicolumn{3}{|c|}{ T2 (900 mm dormant cane) } \\
\hline & $\begin{array}{l}\text { leaf } \\
\text { area } \\
\left(\mathrm{m}^{2}\right)\end{array}$ & $\begin{array}{l}\text { dry } \\
\text { mass } \\
(\mathrm{g})\end{array}$ & $\begin{array}{l}\text { specific } \\
\text { activity } \\
(\mathrm{kBq})\end{array}$ & $\begin{array}{l}\text { leaf } \\
\text { area } \\
\left(\mathrm{m}^{2}\right)\end{array}$ & $\begin{array}{l}\text { dry } \\
\text { mass } \\
(\mathrm{g})\end{array}$ & $\begin{array}{l}\text { specific } \\
\text { activity } \\
(\mathrm{kBq})\end{array}$ \\
\hline $\begin{array}{l}\text { Leaves below } \\
\text { loaded leaf }\end{array}$ & 0,085 & 8,0 & 0 & $0,077^{\text {ns }}$ & $7,0^{\mathrm{ns}}$ & 0 \\
\hline Loaded leaf & 0,0064 & 0,59 & 25,82 & $0,0062^{\mathrm{ns}}$ & $0,78^{\mathrm{ns}}$ & $51,31 * * *$ \\
\hline $\begin{array}{l}\text { Leaves above } \\
\text { loaded leaf }\end{array}$ & 0,1517 & 13,2 & 0,05 & $0,1617^{\mathrm{ns}}$ & $15,4^{\mathrm{ns}}$ & $0,41^{\text {ns }}$ \\
\hline Leaves shoot 2 & 0,2566 & 22,1 & 0 & $0,101^{* * * *}$ & $8,7^{* * *}$ & 0 \\
\hline Total leaves & 0,4998 & 43,89 & 25,87 & $0,346^{* * *}$ & $31,9 * *$ & $51,72^{* * *}$ \\
\hline Roots & & 123,9 & 13,6 & & $120,8^{\mathrm{ns}}$ & $19,4^{* *}$ \\
\hline Cane to root & & 1,33 & 1,04 & & $0,93^{\text {ns }}$ & $2,17^{* *}$ \\
\hline $\begin{array}{l}\text { Shoot below } \\
\text { loaded leaf to cane }\end{array}$ & & 10,9 & 4,45 & & $8,3^{\text {ns }}$ & $6,18^{\text {ns }}$ \\
\hline $\begin{array}{l}\text { Shoot } 2 \text { below } \\
\text { cluster }\end{array}$ & & 18,6 & 0,006 & & $14,4^{\mathrm{ns}}$ & $0,08^{\text {ns }}$ \\
\hline $\begin{array}{l}\text { Shoot above } \\
\text { loaded leaf }\end{array}$ & & 9,9 & 0,52 & & $10,1^{\mathrm{ns}}$ & $0,15^{\mathrm{ns}}$ \\
\hline $\begin{array}{l}\text { Shoot } 2 \text { above } \\
\text { cluster }\end{array}$ & & 19,8 & 0 & & $4,9^{* *}$ & 0 \\
\hline Dormant cane & & 2,0 & 0,48 & & $15,7^{* * * *}$ & $4,93^{* * *}$ \\
\hline Total shoot / cane & & 62,53 & 6,49 & & $54,33^{\text {ns }}$ & $13,51^{* * *}$ \\
\hline Cluster and rachis & & 6,79 & 3,37 & & $6,47^{\mathrm{ns}}$ & $4,05^{* *}$ \\
\hline Plant total & & 237,11 & 49,34 & & $213,5^{\mathrm{ns}}$ & $88,68^{* * *}$ \\
\hline $\begin{array}{l}\text { Non-assimilated } \\
{ }^{14} \mathrm{CO}_{2}\end{array}$ & & & 6,8 & & & $6,47^{\mathrm{ns}}$ \\
\hline Respired ${ }^{14} \mathrm{CO}_{2}$ & & & 128,8 & & & $89,85^{* * * *}$ \\
\hline
\end{tabular}

$\mathrm{ns}=$ no significant difference, ${ }^{*}=$ signifcant difference at $\mathrm{p}<0.05, * *=$ significant difference between paired means at $\mathrm{p}<0.01,{ }^{* * *}=$ significant difference at $\mathrm{p}<0.0001$. 
TABLE 2

Percentage distribution of ${ }^{14} \mathrm{C}$ photoassimilates and percentage of exported (non-respired) ${ }^{14} \mathrm{C}$ photoassimilates (kBq) Vitis vinifera $\mathrm{L}$. cv. Riesling grapevines treated with ${ }^{14} \mathrm{CO}_{2}$ at leaf 10 on the non-fruit-bearing apical shoots carried on $100 \mathrm{~mm}$ (T1) and $900 \mathrm{~mm}(\mathrm{~T} 2)$ canes. Each data point is the mean value of 12 plants.

\begin{tabular}{|c|c|c|c|c|}
\hline \multirow[b]{2}{*}{ Plant organ } & \multicolumn{2}{|c|}{$\mathrm{T} 1$ (100 mm dormant cane) } & \multicolumn{2}{|c|}{ T2 (900 mm dormant cane) } \\
\hline & $\begin{array}{c}\% \\
\text { Distribution } \\
\text { of }{ }^{14} \mathrm{C}\end{array}$ & $\begin{array}{c}\% \\
\text { of Exported/ } \\
\text { Non-Respired }{ }^{14} \mathrm{C}\end{array}$ & $\begin{array}{l}\% \\
\text { Distribution } \\
\text { of }{ }^{14} \mathrm{C}\end{array}$ & $\begin{array}{c}\% \\
\text { of Exported/ } \\
\text { Non-Respired }{ }^{14} \mathrm{C}\end{array}$ \\
\hline $\begin{array}{l}\text { Leaves below } \\
\text { loaded leaf }\end{array}$ & 0 & 0 & 0 & 0 \\
\hline Loaded leaf & 52,3 & & $57,85^{\text {ns }}$ & \\
\hline $\begin{array}{l}\text { Leaves above } \\
\text { loaded leaf }\end{array}$ & 0,1 & 0,21 & $0,46^{* *}$ & $1,09^{* *}$ \\
\hline Leaves shoot 2 & 0 & 0 & 0 & 0 \\
\hline Roots & 27,56 & 57,82 & $21,87^{\mathrm{ns}}$ & $51,9^{\mathrm{ns}}$ \\
\hline Cane to root & 2,11 & 4,42 & $2,45^{\text {ns }}$ & $5,81^{\text {ns }}$ \\
\hline $\begin{array}{l}\text { Shoot below } \\
\text { loaded leaf to cane }\end{array}$ & 9,02 & 18,92 & $6,97^{\mathrm{ns}}$ & $16,54^{* *}$ \\
\hline $\begin{array}{l}\text { Shoot } 2 \text { below } \\
\text { cluster to cane }\end{array}$ & 0,01 & 0,03 & $0,09^{\text {ns }}$ & $0,21^{\mathrm{ns}}$ \\
\hline $\begin{array}{l}\text { Shoot above } \\
\text { loaded leaf }\end{array}$ & 1,06 & 2,21 & $0,17^{* *}$ & $0,39^{* *}$ \\
\hline $\begin{array}{l}\text { Shoot } 2 \text { above } \\
\text { cluster }\end{array}$ & 0 & 0 & 0 & 0 \\
\hline Dormant cane & 0,97 & 2,04 & $5,56^{* * *}$ & $13,19^{* * *}$ \\
\hline Cluster and rachis & 6,83 & 14,33 & $4,56^{*}$ & $10,84^{*}$ \\
\hline
\end{tabular}

ns $=$ no significant difference, ${ }^{*}=$ signifcant difference at $\mathrm{p}<0.05,{ }^{*}=$ significant difference between paired means at $\mathrm{p}<0.01,{ }^{* * *}=$ significant difference at $\mathrm{p}<0.0001$. 


\section{CONCLUSIONS}

Partitioning of over $50 \%$ of the exported ${ }^{14} \mathrm{C}$ photoassimilates to the roots was demonstrated in both treatments, indicating that sink hierarchy has been altered. The high leaf area to fresh fruit ratios and the limiting of cluster size may have affected sink strength of the cluster as well as partitioning of ${ }^{14} \mathrm{C}$ photoassimilates, the majority being directed to the roots. Minimal translocation of ${ }^{14} \mathrm{C}$ photoassimilates from source leaves on non-fruit-bearing shoots was directed towards the clusters located on the lower shoot, which supports the findings of Stewart et al. (1996). ${ }^{14} \mathrm{C}$ photoassimilates from the loaded source leaf were mainly supporting root growth carbohydrate accumulation. This pool of carbohydrate reserve will initially supply the new developing shoots in the following growing season. The results of this experiment concurred with the results of Hunter \& Visser (1988a) and Stewart et al. (1996), where bi-directional translocation of ${ }^{14} \mathrm{C}$ photoassimilates was demonstrated. The partitioning of a small percentage of ${ }^{14} \mathrm{C}$ photoassimilates acropetally in the post-véraison period is presumably to support the respiration and maintenance requirements of the shoot and immature leaves at the apex.

\section{LITERATURE CITED}

HUNTER, J.J. \& VISSER, J.H., 1988a. Distribution of ${ }^{14} \mathrm{C}$ - photosynthate in the shoot of Vitis vinifera L. I. The effect of leaf position and developmental stage of the vine. S. Afr. J. Enol. Vitic. 9, 3-9.

HUNTER, J.J. \& VISSER, J.H., 1988b. Distribution of ${ }^{14} \mathrm{C}$ - photosynthate in the shoot of Vitis vinifera L. cv. Cabernet Sauvignon. II. The effect of partial defoliation. S. Afr. J. Enol. Vitic. 9, 10-15.

MOTOMURA, Y., 1990. Distribution of ${ }^{14} \mathrm{C}$ assimilates from individual leaves on clusters in grape shoots. Am. J. Enol. Vitic. 41, 307-312.

MOTOMURA, Y., 1993. ${ }^{14} \mathrm{C}$ assimilate partitioning in grapevine shoots: Effects of shoot pinching, girdling of shoot, and leaf halving on assimilates partitioning from leaves into clusters. Am. J. Enol. Vitic. 44, 1-7.

QUINLAN, J.D. \& WEAVER, R.W., 1970. Modification of patterns of photosynthate movement between shoots of Vitis vinifera L. Plant Physiology 46, 527-530.

SMART, R.E., DICK, J.K., GRAVATT, I.M. \& FISHER, B.M., (1990). Canopy management to improve grape yield and wine quality - Principles and practices. S. Afr. J. Enol. Vitic. 11, 3-17.

SNEDECOR, G.W. \& COCHRANE, W.G., 1969. Statistical Methods. 6th ed. Iowa State University Press, Iowa, U.S.A.

STEWART, W.P., FREEMAN, B.M. \& DICK, J.K., 1996. Source leaf position and carbon partitioning in a single shoot of post-véraison Vitis vinifera L. cv. Riesling. Aust. Grapegr. \& Winemaker 390a, 65-69. 